\title{
Picidae in the European fossil, subfossil and recent bird faunas and their osteological characteristics
}

\author{
Jenő (Eugen) KeSSLER
}

Received: February 18, 2016 - Accepted: May 30, 2016

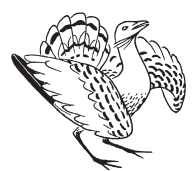

Jenö (Eugen) Kessler 2016. Picidae in the European fossil, subfossil and recent bird faunas and their osteological characteristics. - Ornis Hungarica 24(1): 96-114.

images of the osteological characteristics of the order's 10 recent European species.

Skeletal parts that are usually present both in the fossil and subfossil material were examined (mandibula, coracoideum, scapula, humerus, ulna, metacarpus, the first phalanx of the second finger of the wing, femur, tibiotarsus, tarsometatarsus and distal phalanx). The text is complemented with the bibliography concerning the fossilized material, tables and figures and a size chart.

Keywords: paleornithology, osteology, Paleogene, Neogene

Összefoglalás A dolgozatban a harkályok rendjének európai fosszilis, szubfosszilis és recens képviselőit mutatja be a szerző. A fosszilis és szubfosszilis maradványok felsorolását követően a szerző a rend 10 európai recens fajának csonttani jellegeit elemzi és mutatja be képeken is. A vázrészek közül azok kerülnek vizsgálatra, amelyek a fosszilis és szubfosszilis anyagban is rendszerint jelen vannak (alsó állkapocs, hollócsőrcsont, lapocka, felkarcsont, singcsont, kézközépcsont, a szárny II. ujjának első ujjperce, combcsont, lábszárcsont, csüd és karomcsont). A szöveget kiegészíti a fosszilis anyagot felölelő könyvészeti jegyzék, 8 táblakép és egy mérettáblázat.

Kulcsszavak: paleornitológia, csonttan, paleogén, neogén

Department of Paleontology, Eötvös Loránd University, 1117 Budapest, Pázmány Péter sétány 1/c, Hungary, e-mail: kessler_jeno@yahoo.com

\section{Introduction}

Representatives of the order Picidae were present in Europe already in the beginning of the Paleogene, represented by species of the presently exclusively tropical family (Capitonidae) or the now extinct family (Zygodactylidae). These are, for example, the Primozygodactylus eunjoae Mayr and Zelenkov, 2009 (Mayr 2005c, 2006, Mayr \& Zelenkov 2009), from the Middle Eocene of Messel Grube, Germany, the Zygodactylus luberonensis Mayr, 2008, from the Lower Ogliocene of France (Mayr 2005b, 2008) and multiple findings from the Miocene of France and Germany (Zygodactylus ignotus Ballmann, 1966, and Capitonides europaeus Ballmann, 1966, from the Middle Miocene of Wintershof(West) bei Eicstätt, Z. grivensis Ballmann, 1969, and Z. gaudryi (Depéret 1887), from the Middle Miocene of La Grive-Saint-Alban) (Ballmann 1966, 1969a, 1969b). The small Rupelramphastoides kopfi Mayr, 2005 from the Lower Oligocene site of Freuenweiler, Germany, is thought to belong to the Ramphastidae family (Mayr 
2005a). Picavus litencicensis Mayr and Gregorova (2012) described from the Litenčice site of the Czech Republic also comes from the Lower Oligocene (Mayr \& Gregorova 2012).

The recent Picidae, however, are only known from the Neogene of Europe in quite scarce numbers and without exception represented by modern genera:

- Picus peregrinabundus Umans'ka, 1981 from the Upper Miocene of Novoelisavetovka, Ukraine (MN 11-12) (Umanska 1981, Mlikovský 2002)

- Picus pliocaenicus Kessler, 2013 from the Lower Pliocene of Beremend 26, Hungary (MN 15) (Kessler 2013)

- Dendrocopos praemedius Jánossy, 1974 from the Upper Pliocene of Villány 3, Hungary (MN 16-17) (Jánossy 1974) and subsequently from site Beremend 26 (Kessler 2009, 2013)

- the extinct Dendrocopos submajor Jánossy, 1974 was described by Dénes Jánossy (1974) from the Upper Pleistocene of Hundsheim, Austria, but Mlikovský (2002) synonymized the latter with the species D. major as he did the former with the recent $D$. medius. Given that the author identified both species from the much older site of Beremend 26, we are on the opinion that according to the sizes and characteristics, the former should be viewed as a valid species, while the latter as a subspecies (D. major submajor).

The marking of the recent Pogoniulus genus belonging to the Ramphastidae family by Mlikovský (2002) from the Upper Miocene of Austria is also worth mentioning (Kohfidisch - Gyepüfüzes).

Recent species of the Picidae family are only specific to the Pleistocene and Holocene of Europe:

- Jynx torquilla Linnaeus, 1758

Known from the Lower Pleistocene: Betfia 2 (Kormos 1913, Čapek 1917) and Upper Pleistocene of the Carpathian Basin: the shelter cave of Hámor-Puskaporos (Lambrecht 1912, 1916, 1933, Jánossy 1977, 1986), as well as the Middle Pleistocene of France and the Upper Pleistocene of Austria, the Czech Republic, France, Croatia, Germany, Switzerland and Romania (Tyrberg 1997).

\section{- Picus viridis Linnaeus, 1758}

Known from the Lower Pleistocene: Betfia 9 (Gál 2002), Somssich Hill 2 (Jánossy 1981a, 1982b, 1983, 1986), Middle Pleistocene: Tarkő 1-16 (Jánossy 1977) and Upper Pleistocene: Varbó-Lambrecht Kálmán Cave (Jánossy 1977), the Holocene: Kazánszoros-Töröklik Cave (Kessler 1974), Körösbánlaka Cave (Kessler 1982), Vársonkolyos-Izbîndiş Cave, (Kessler 1977, Gál 2002), the caves of Vársonkolyos (Kessler 1982), as well as the Middle Pleistocene of France, Italy, Spain and the Upper Pleistocene of England, Austria, the Czech Republic, France, Croatia, Germany, Italy and Spain (Tyrberg 1997).

- Picus canus Linnaeus, 1758

Known from the Upper Pleistocene of the Carpathian Basin: Felsőtárkány-Peskő Cave (Lambrecht 1912, 1933, Jánossy 1977), Nándor-Nándori Cave (Jánossy 1965, Fischer \& Stephan 1977, Kessler 1985, Jurcsák \& Kessler 1988, Gál 2002, 2003), Óruzsin-Antal Cave (Nehring 1880, Róth 1881, Lambrecht 1912, 1933), shelter cave I. of Pilisszántó (Lambrecht 1915, 1933, 
Jánossy 1977, 1986), Répáshuta-Balla Cave (Lambrecht 1912, 1933), Varbó-Lambrecht Kálmán Cave (Jánossy 1977), Velika Pecina (V. Malez 1975, 1984, 1988), Velika pec na Lipi (V. Malez 1975, 1984, 1993, V. Malez-Bačić 1975), the Holocene: Felsőtárkány-Petény Cave (Jánossy 1977), as well as the Middle Pleistocene of the Czech Republic, France and the Upper Pleistocene of Austria, the Czech Republic, France, Germany, Italy and Switzerland (Tyrberg 1997).

\section{- Picus sp.}

Known from the Upper Pleistocene of the Carpathian Basin: the shelter cave of Hámor-Puskaporos (Lambrecht 1912, 1916, 1933, Jánossy 1977, 1986), as well as the Upper Pleistocene of Luxemburg and Germany (Tyrberg 1997).

- Dryocopus martius (Linnaeus, 1758)

Known from the Upper Pleistocene of Georgia, France and Poland (Tyrberg 1997).

\section{- Dendrocopos major (Linnaeus, 1758)}

Known from the Middle Pleistocene: Vindija (M. Malez 1961, V. Malez 1973, 1988, 1991), and Upper Pleistocene: Bajót-Jankovich Cave (Lambrecht 1933, Jánossy 1977), Budapest-Remetehegy Shelter Cave (Kormos \& Lambrecht 1914, Lambrecht 1933, Jánossy 1977, 1986), the shelter cave of Hámor-Puskaporos (Lambrecht 1912, 1916, 1933, Jánossy 1977, 1986), Hámor-Herman Ottó Cave (Lambrecht 1915, 1933), Merkenstein (Wettstein \& Mühlhofer 1938), shelter cave I. of Pilisszántó (Lambrecht 1915, 1933, Jánossy 1977, 1986), Szegyestel-Măgura Cave (Kessler 1982, 1985, Gál 2002), Szilvásvárad-Istállóskő Cave (Lambrecht 1912, 1933, Jánossy 1952, 1955, 1977), Tatabánya-Szelim Cave (Jánossy 1977), Velika Pecina (V. Malez 1975, 1984, 1988) and from the Holocene of Ecsegfalva n. 23 (Pike-Tay et al. 2004, Gál 2007b), Felsőtárkány-Petény Cave (Jánossy 1977), Legény Cave (Lambrecht 1914), the shelter cave of Répáshuta-Rejtek (Jánossy 1977), Teufelslucken (Soergel 1966), as well as the Lower Pleistocene of France and Spain, the Middle Pleistocene of the Czech Republic, France, Croatia, Germany, Italy, Spain, and the Upper Pleistocene of England, Bosnia and Herzegovina, the Czech Republic, France, Ireland, Poland, Germany, Italy, Spain, Switzerland and Ukraine (Tyrberg 1997).

\section{- Dendrocopos medius (Linnaeus, 1758)}

Known from the Lower Pleistocene: Betfia 2, 9 (Kormos 1913, Čapek 1917, Lambrecht 1933, Kessler 1975, Jánossy 1977, Gál 2002), Middle Pleistocene: Hundsheim (Jánossy 1974), Tarkő 4, 11 (Jánossy 1977) and Upper Pleistocene, Óruzsin-Antal Cave (Nehring 1880, Róth 1881, Lambrecht 1912, 1933), Velika Pecina (V. Malez 1975, 1984, 1988), as well as the Lower Pleistocene of Ukraine, the Middle Pleistocene of France, the Upper Pleistocene of France, Germany, Italy and Ukraine (Tyrberg 1997).

- Dendrocopos minor (Linnaeus, 1758)

Known from the Lower Pleistocene of the Carpathian Basin: Betfia 9 (Gál 2002), as well as the Lower Pleistocene of England, middle Pleistocene of France, and Upper Pleistocene of England, France and Croatia (Tyrberg 1997). 
- Dendrocopos leucotos (Bechstein 1803)

Known from the Holocene of the Carpathian Basin: Felsőtárkány-Petény Cave (Jánossy 1977), as well as the Middle Pleistocene of France, Italy, and the Upper Pleistocene of Austria, Belgium, France, Greece and Italy (Tyrberg 1997).

- Picoides tridactylus (Linnaeus, 1758)

Known from the Middle Pleistocene of France and the Upper Pleistocene of Germany (Tyrberg 1997).

\section{Palaeoecological conclusions}

The changes in climate across Europe by the end of the Miocene, seasonal cooling and warming were not favorable for fruit-eating types (Coliiformes, Musophagiformes, Psitaciformes, beside Trogoniformes from among the families of Piciformes (the representatives of Capitonidae, Ramphastidae and Zygodactylidae) - thus, these receded back to tropical areas. Members of the Picidae family in the Piciformes order were able to withstand the seasonal changes in temperature as insectivores, mostly specializing on invertebrates living under tree bark. The sole exception is the less specialized Eurasian wryneck with beaks incapable of carving, which is the only migrating species of the family and not only does it not show any specialization in its skull, but also its flight capabilities and tail feathers are unlike those of other species.

For the latter, the thickening of the parietal bones, the rather strong lower and upper jaws, the remarkably long tongue, the flight feathers capable of weight support all had significant effects on flight capabilities, and consequently the shape and size of the wings. The distinctively wavelike trajectory and low flight speed would not allow for longer migration at this point, which they do not need in their woodland habitats, however, it serves perfectly well motion in this environment. The geographic spread of the approximately 300 species of the family supports the above statement, since they were unable to reach Oceania, Madagascar, Australia and New-Zealand. An extremely complex, data-rich study appeared recently (Winkler 2015), which perfectly complements this work.

\section{Osteological characteristics of Picidae}

From an osteological perspective, their skeletal parts can easily be identified, but the current paper only takes into account those that easily remain, fossilize and can be identified up to species level. These are the mandible, the coracoid bone of the pectoral girdle, the scapula, bones of the upper and lower limbs (apart from the radial bone, fibula and certain phalanges), so we do not examine neither the otherwise typical skull, sternum and pelvis, nor the vertebrae, ribs and furcula (Plate 1). 


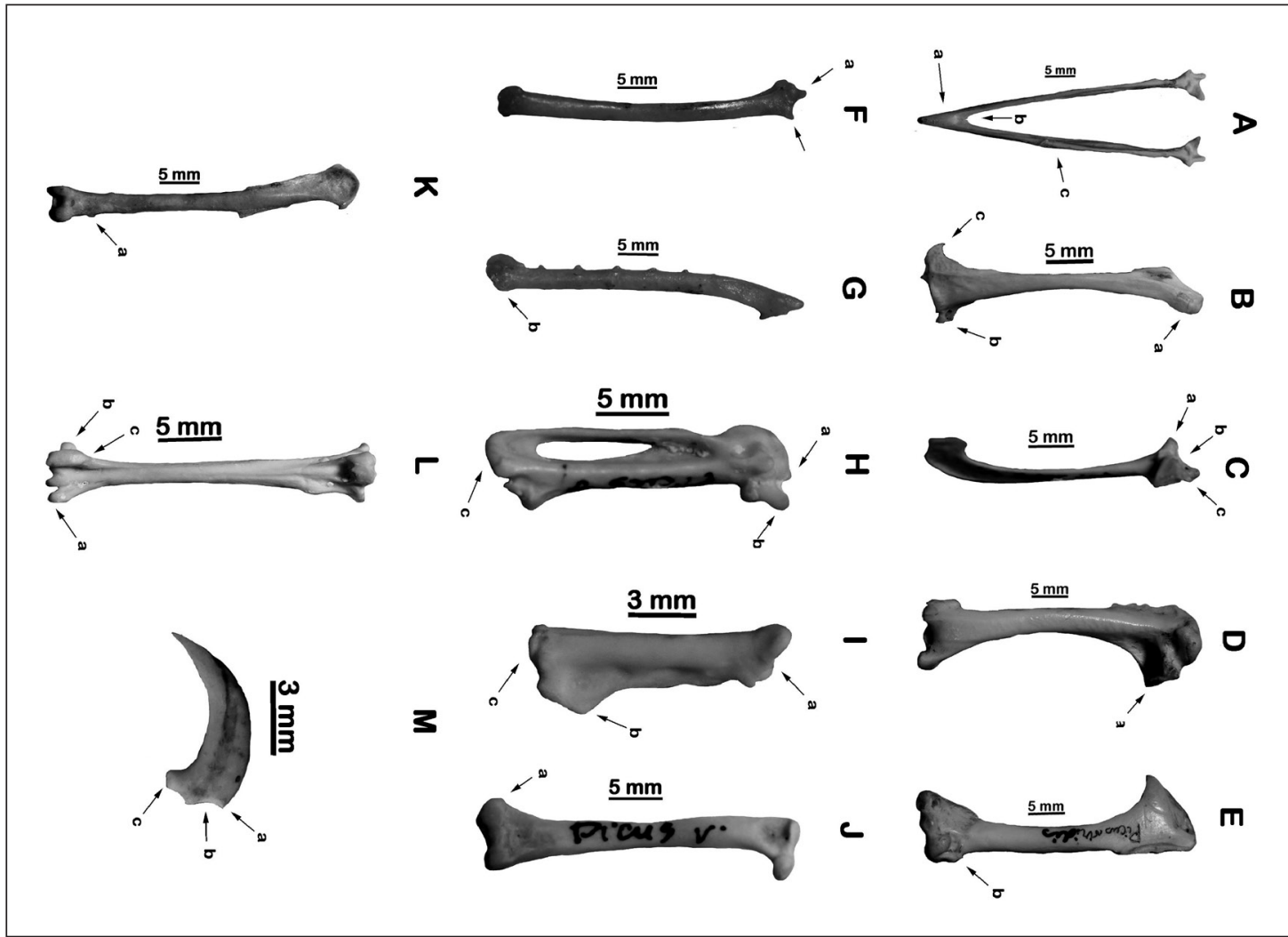

$\frac{0^{2}}{\frac{9}{9}}$

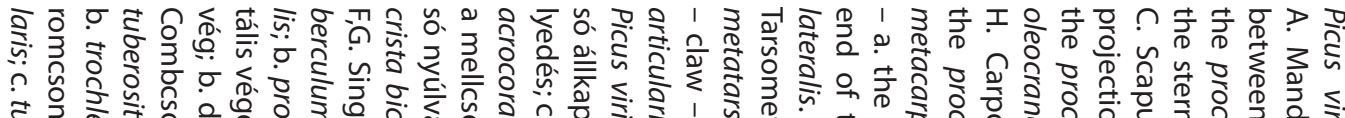

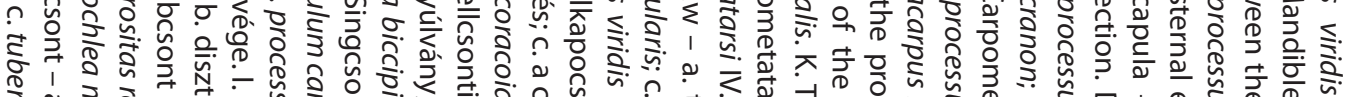

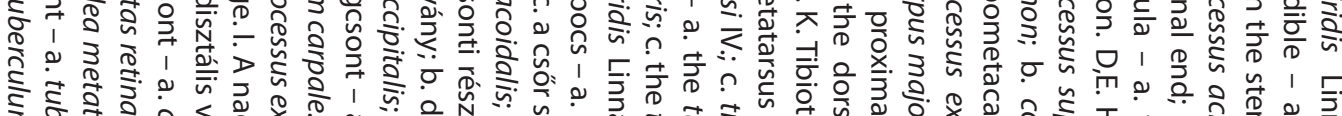

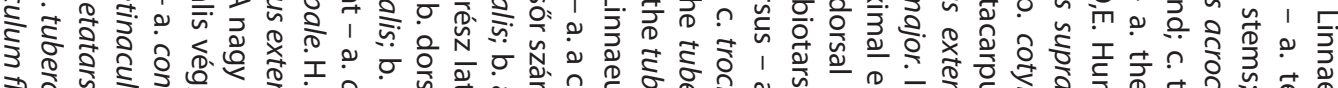

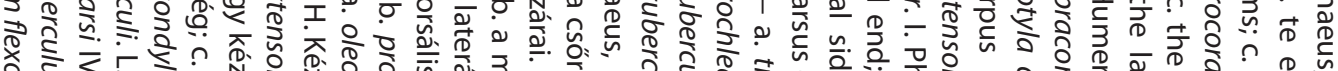

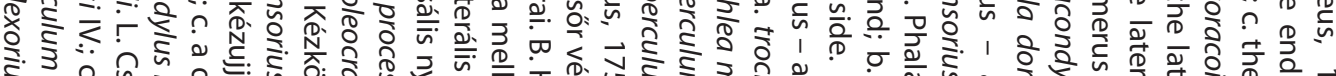

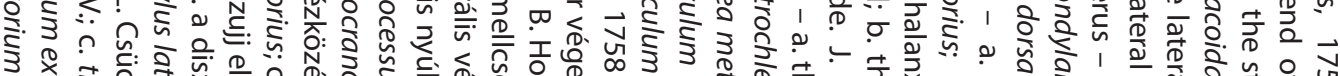

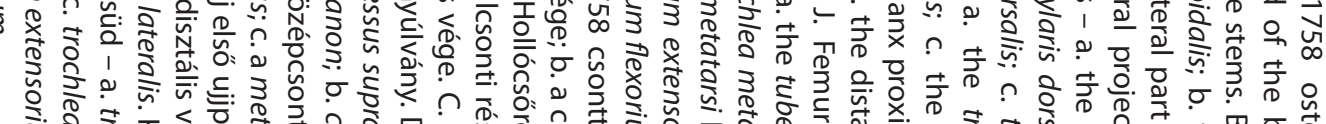

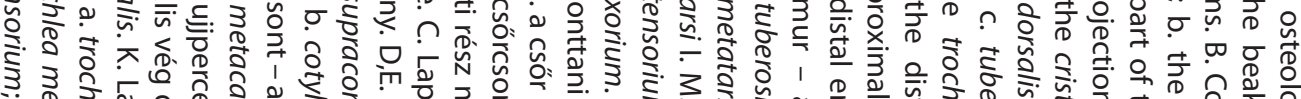

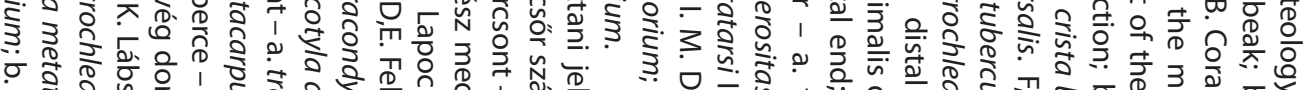

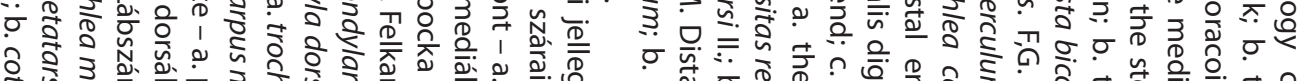

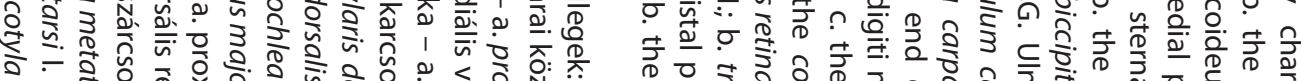

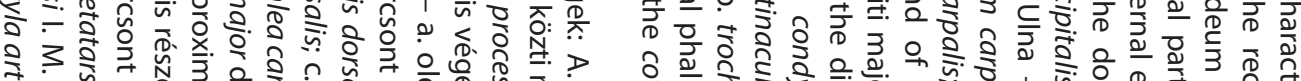

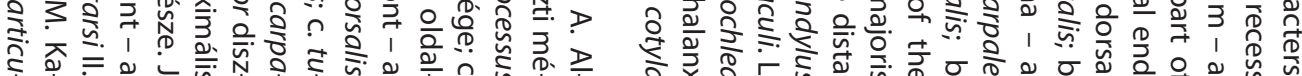




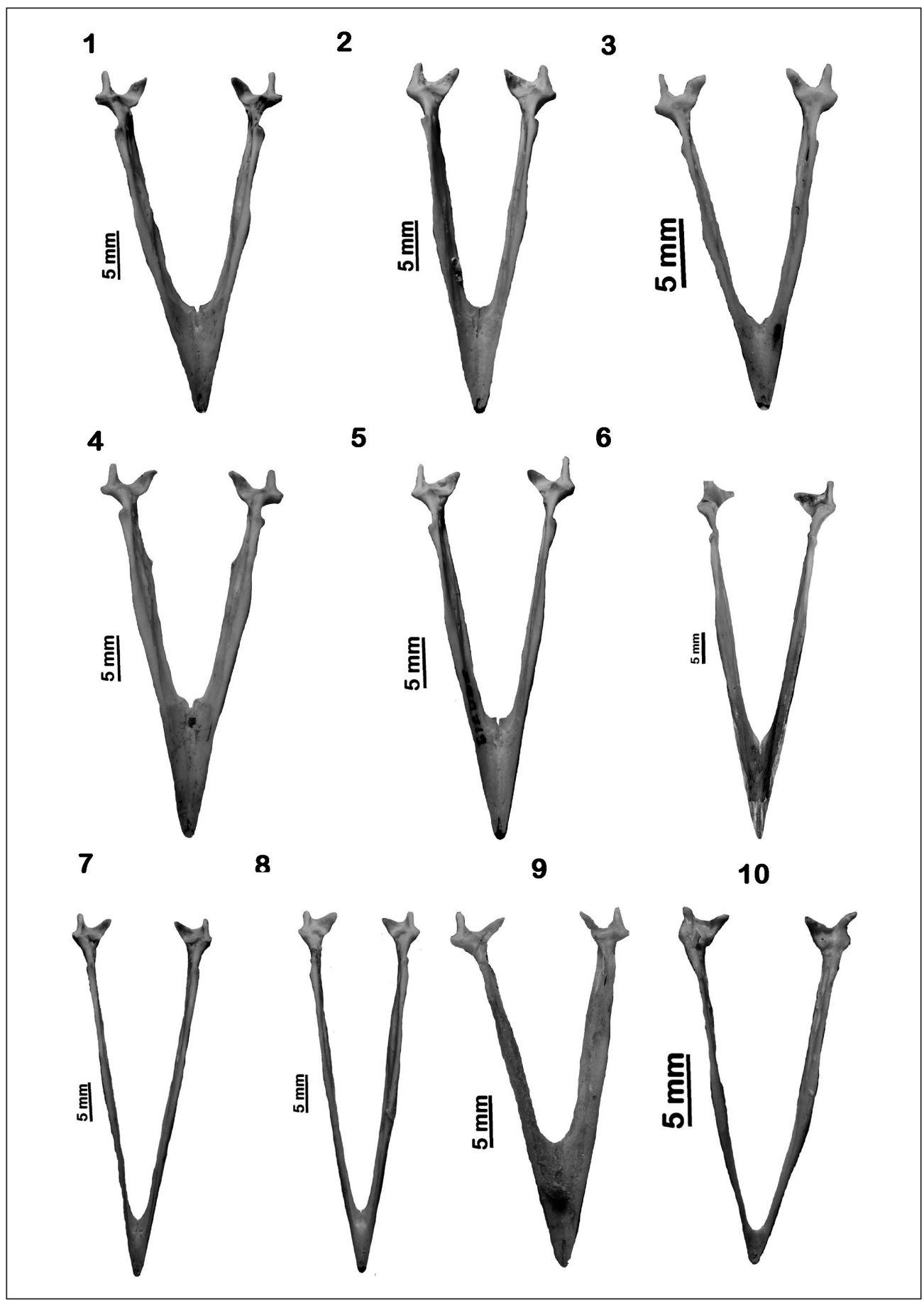

Plate 2. $\quad$ Mandibula, dorsal aspect: 1. Dendrocopos major; 2. Dendrocopos medius; 3. Dendrocopos minor; 4. Dendrocopos leucotos; 5. Dendrocopos syriacus; 6. Dryobates martius; 7. Picus canus; 8. Picus viridis; 9. Picoides tridactylus; 10. Jynx torquilla

Táblakép 2. Alsó állkapocs, dorsális nézet: 1. Dendrocopos major; 2. Dendrocopos medius; 3. Dendrocopos minor; 4. Dendrocopos leucotos; 5 . Dendrocopos syriacus; 6. Dryobates martius; 7. Picus canus; 8. Picus viridis; 9. Picoides tridactylus; 10 . Jynx torquilla 


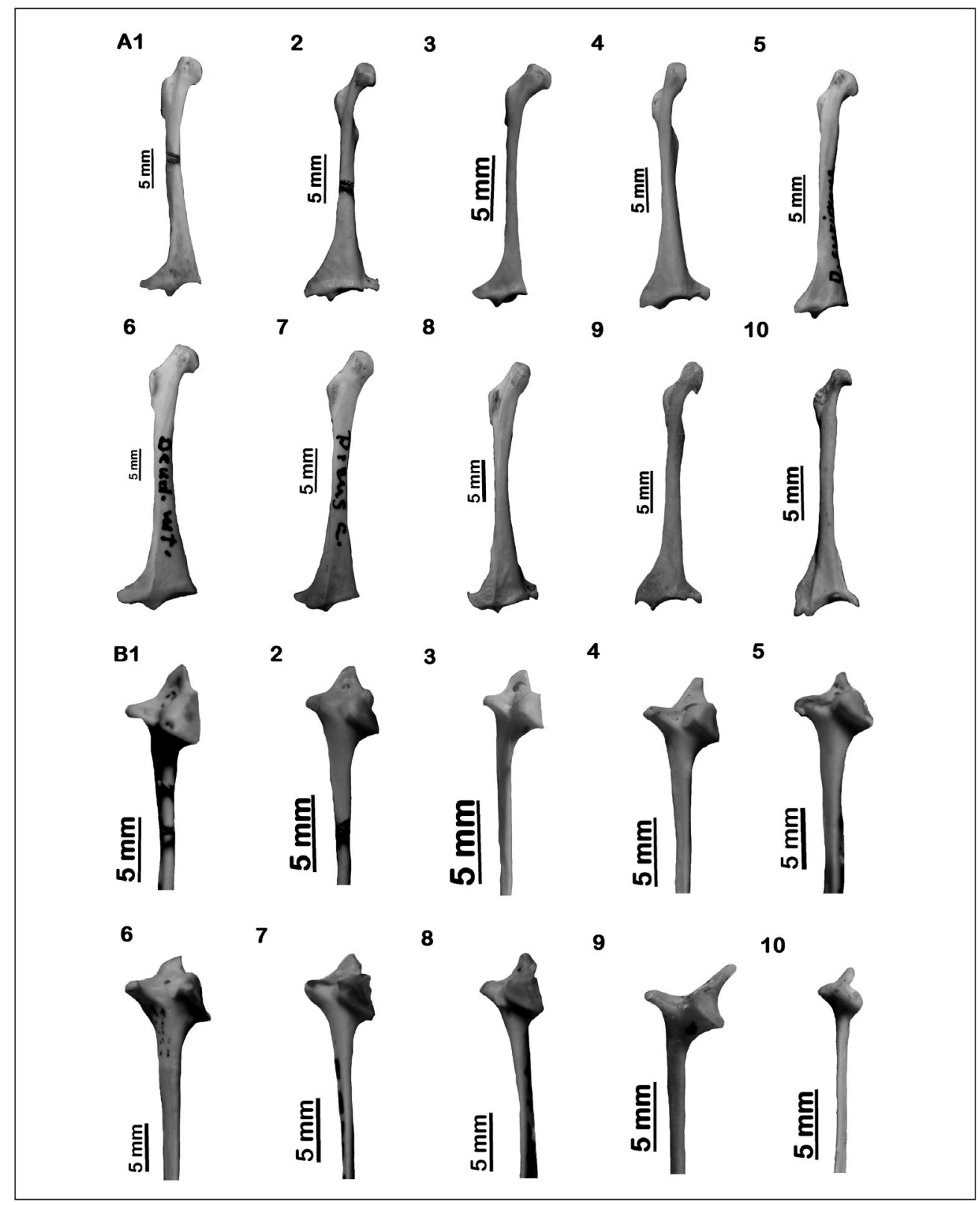

Plate 3. A. Coracoideum, right side, ventral surface: 1. Dendrocopos major; 2. Dendrocopos medius; 3. Dendrocopos minor; 4. Dendrocopos leucotos; 5. Dendrocopos syriacus; 6. Dryobates martius; 7. Picus canus; 8. Picus viridis; 9. Picoides tridactylus; 10. Jynx torquilla

B. Scapula, left side, medial surface: 1. Dendrocopos major; 2. Dendrocopos medius; 3. Dendrocopos minor; 4. Dendrocopos leucotos; 5. Dendrocopos syriacus; 6. Dryobates martius; 7. Picus canus; 8. Picus viridis; 9. Picoides tridactylus; 10. Jynx torquilla

Táblakép 3. A. Hollócsőrcsont, jobboldali, ventrális nézet: 1. Dendrocopos major; 2. Dendrocopos medius; 3. Dendrocopos minor; 4. Dendrocopos leucotos; 5. Dendrocopos syriacus; 6. Dryobates martius; 7. Picus canus; 8. Picus viridis; 9. Picoides tridactylus; 10. Jynx torquilla.

B. Lapocka, baloldali, mediális nézet: 1. Dendrocopos major; 2. Dendrocopos medius; 3. Dendrocopos minor; 4. Dendrocopos leucotos; 5. Dendrocopos syriacus; 6. Dryobates martius; 7. Picus canus; 8. Picus viridis; 9. Picoides tridactylus; 10. Jynx torquilla 


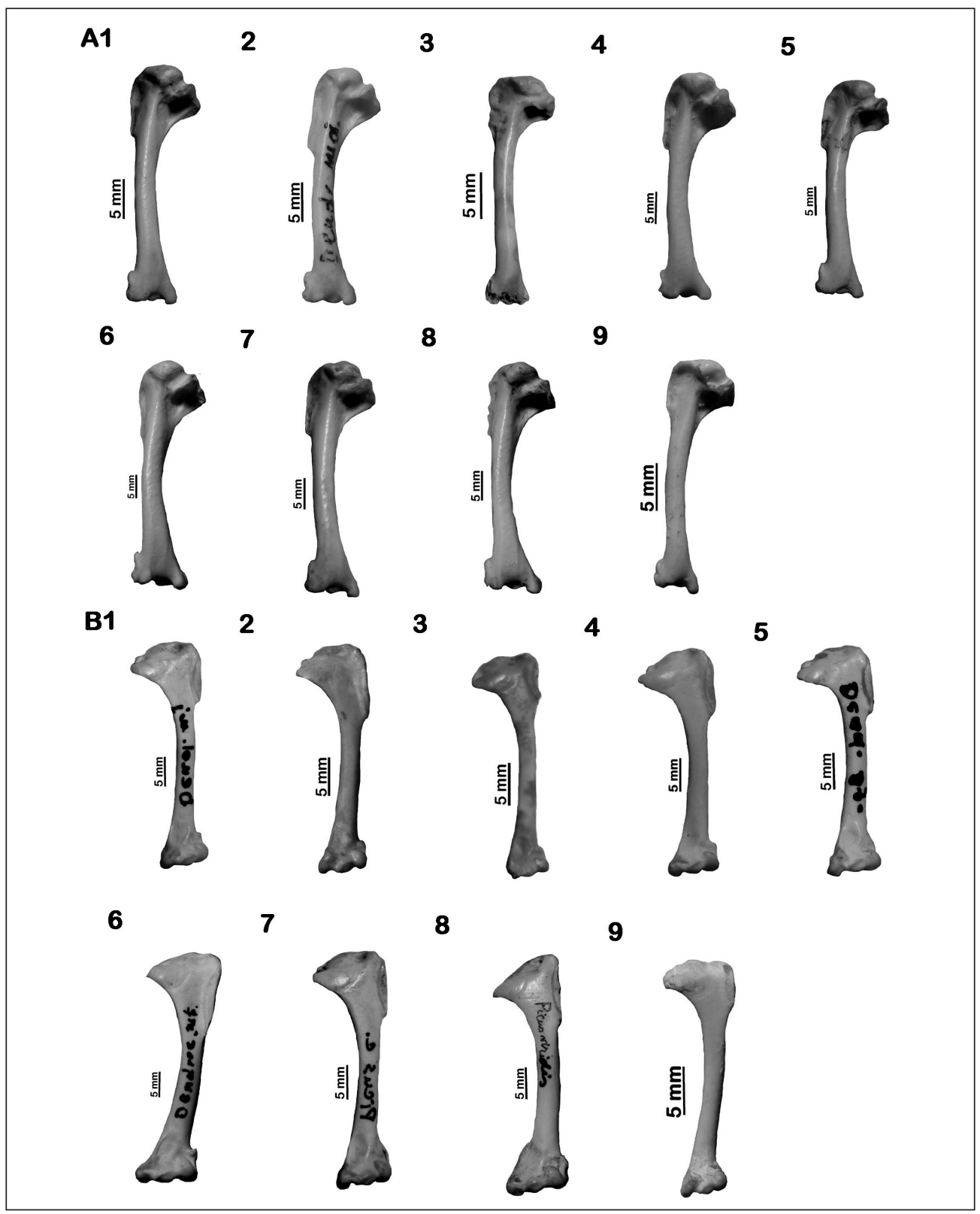

Plate 4. A. Humerus, left side, caudal surface: 1. Dendrocopos major; 2. Dendrocopos medius; 3. Dendrocopos minor; 4. Dendrocopos leucotos; 5. Dendrocopos syriacus; 6. Dryobates martius; 7. Picus canus; 8. Picus viridis; 9. Jynx torquilla.

B. Humerus, left side, cranial surface: 1. Dendrocopos major; 2. Dendrocopos medius; 3. Dendrocopos minor; 4. Dendrocopos leucotos; 5. Dendrocopos syriacus; 6. Dryobates martius; 7. Picus canus; 8. Picus viridis; 9. Jynx torquilla

Táblakép 4. A. Felkarcsont, baloldali, caudális nézet: 1. Dendrocopos major; 2. Dendrocopos medius; 3. Dendrocopos minor; 4. Dendrocopos leucotos; 5. Dendrocopos syriacus; 6. Dryobates martius; 7. Picus canus; 8. Picus viridis; 9. Jynx torquilla.

B. Felkarcsont, baloldali, craniális nézet: 1. Dendrocopos major; 2. Dendrocopos medius; 3. Dendrocopos minor; 4. Dendrocopos leucotos; 5. Dendrocopos syriacus; 6. Dryobates martius; 7. Picus canus; 8. Picus viridis; 9. Jynx torquilla 


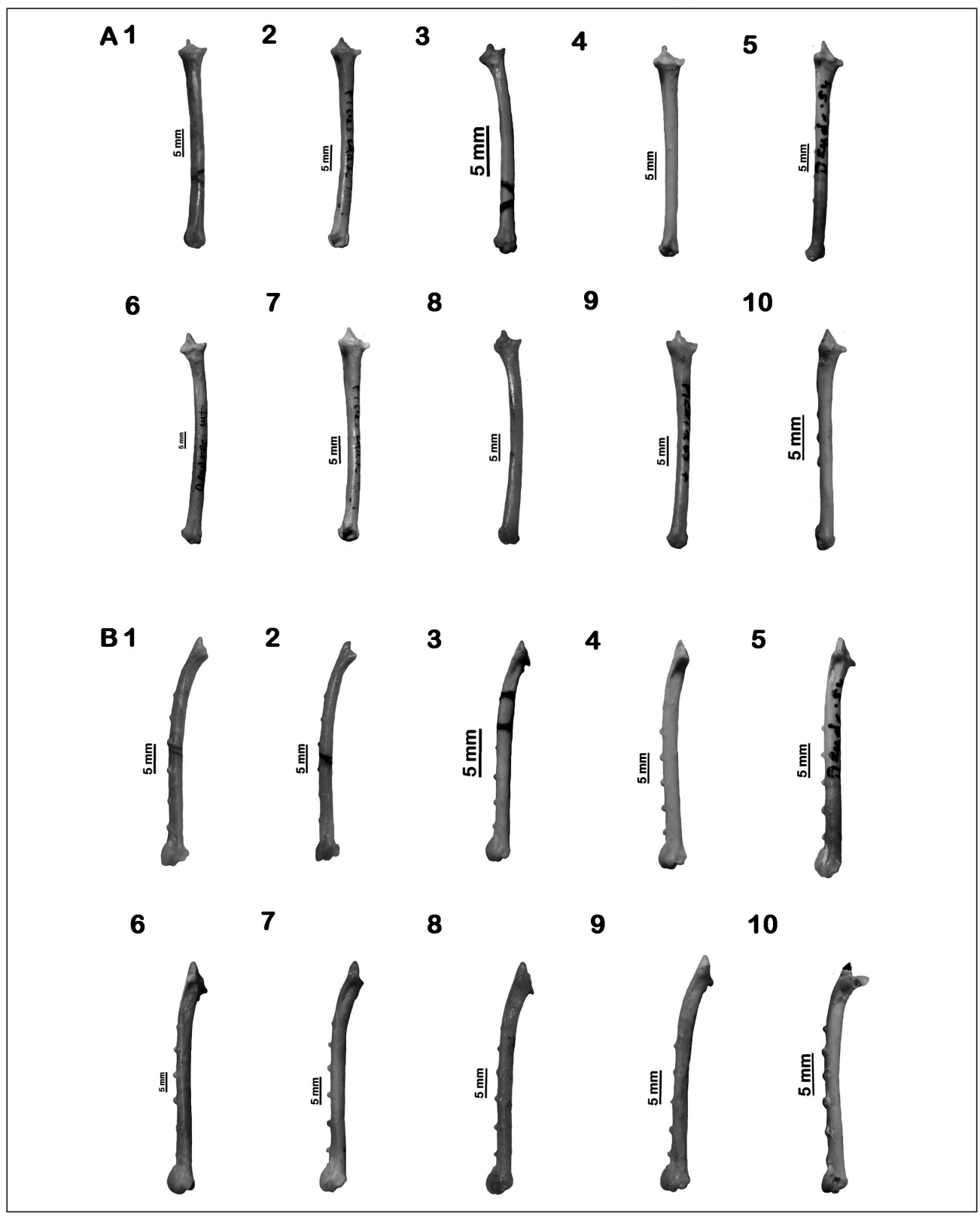

Plate 5. A. Ulna, right side, dorsal surface: 1. Dendrocopos major; 2. Dendrocopos medius; 3. Dendrocopos minor; 4. Dendrocopos leucotos; 5. Dendrocopos syriacus; 6. Dryobates martius; 7. Picus canus; 8. Picus viridis; 9. Picoides tridactylus; 10. Jynx torquilla

B. Ulna, right side, medial surface: 1. Dendrocopos major; 2. Dendrocopos medius; 3. Dendrocopos minor; 4. Dendrocopos leucotos; 5. Dendrocopos syriacus; 6. Dryobates martius; 7. Picus canus; 8. Picus viridis; 9. Picoides tridactylus; 10. Jynx torquilla

Táblakép 5. A. Singcsont, jobboldali, dorsális nézet: 1. Dendrocopos major; 2. Dendrocopos medius; 3. Dendrocopos minor; 4. Dendrocopos leucotos; 5. Dendrocopos syriacus; 6. Dryobates martius; 7. Picus canus; 8. Picus viridis; 9. Picoides tridactylus; 10. Jynx torquilla

B. Singcsont, jobboldali, mediális nézet: 1. Dendrocopos major; 2. Dendrocopos medius; 3. Dendrocopos minor; 4. Dendrocopos leucotos; 5. Dendrocopos syriacus; 6. Dryobates martius; 7. Picus canus; 8. Picus viridis; 9. Picoides tridactylus; 10. Jynx torquilla 


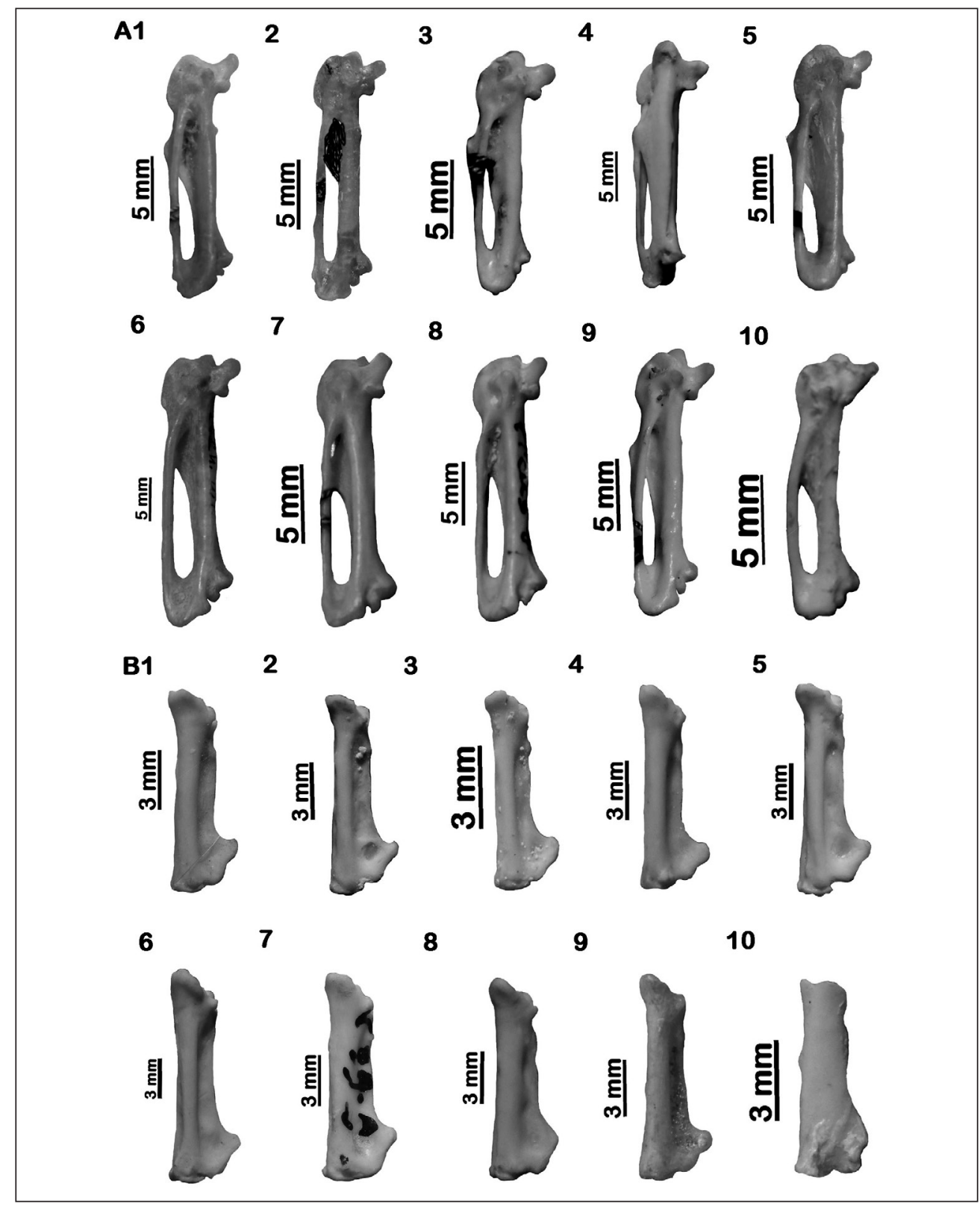

Plate 6. A. Carpometacarpus, left side, ventral aspect: 1. Dendrocopos major; 2. Dendrocopos medius; 3. Dendrocopos minor; 4. Dendrocopos leucotos; 5. Dendrocopos syriacus; 6. Dryobates martius; 7. Picus canus; 8. Picus viridis; 9. Picoides tridactylus; 10. Jynx torquilla.

B. Phalanx proximalis digiti majoris, left side, dorsal aspect: 1. Dendrocopos major; 2. Dendrocopos medius; 3. Dendrocopos minor; 4. Dendrocopos leucotos; 5. Dendrocopos syriacus; 6. Dryobates martius; 7. Picus canus; 8. Picus viridis; 9. Picoides tridactylus; 10. Jynx torquilla

Táblakép 6. A. Kézközépcsont, baloldali, ventrális nézet: 1 . Dendrocopos major; 2 . Dendrocopos medius; 3. Dendrocopos minor; 4. Dendrocopos leucotos; 5. Dendrocopos syriacus; 6. Dryobates martius; 7. Picus canus; 8. Picus viridis; 9. Picoides tridactylus; 10. Jynx torquilla.

B. II. jj, 1.ujjperc, baloldali, dorsális nézet: 1. Dendrocopos major; 2. Dendrocopos medius; 3. Dendrocopos minor; 4. Dendrocopos leucotos; 5. Dendrocopos syriacus; 6. Dryobates martius; 7. Picus canus; 8. Picus viridis; 9. Picoides tridactylus; 10. Jynx torquilla 


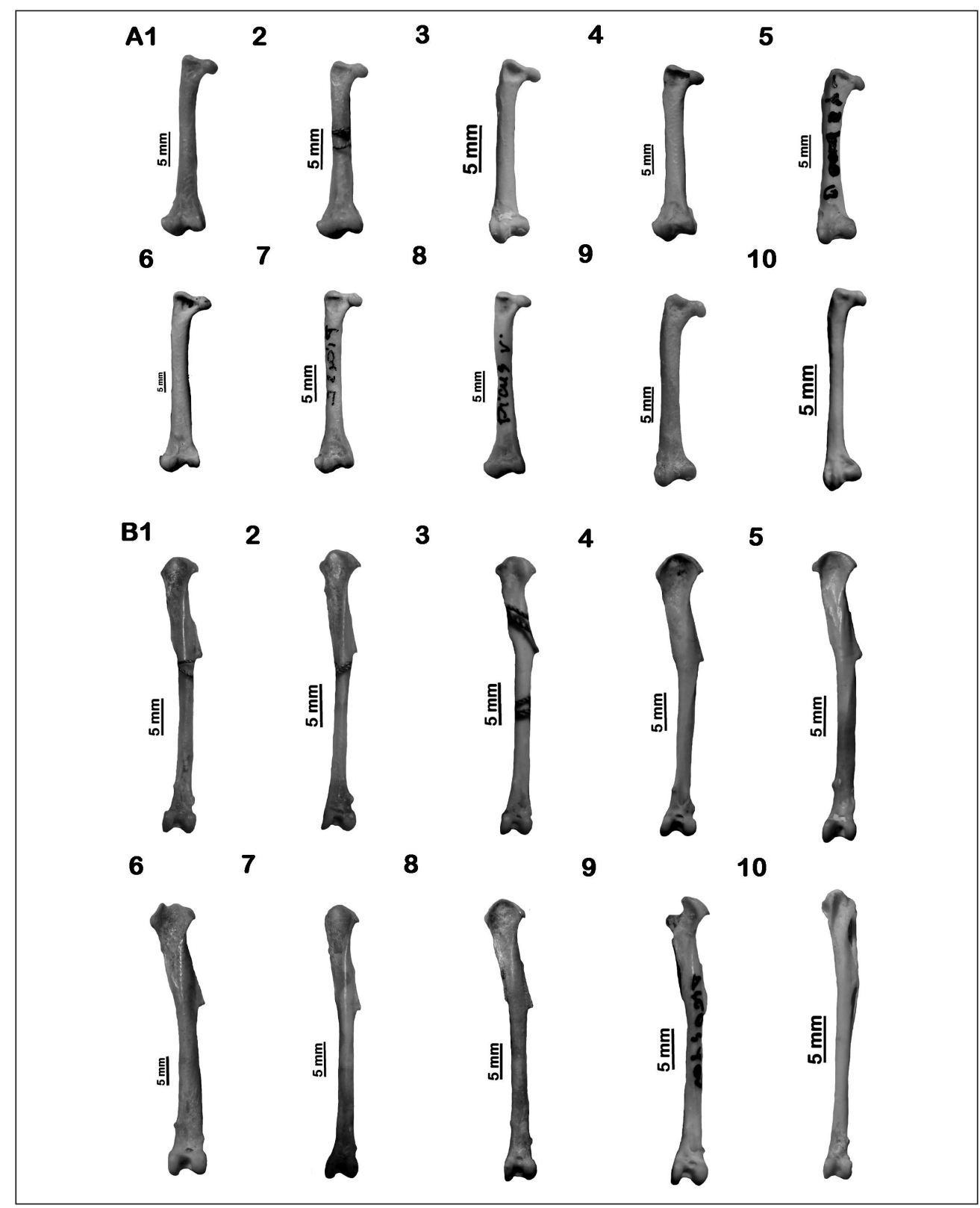

Plate 7. A. Femur, left side, caudal aspect: 1. Dendrocopos major; 2. Dendrocopos medius; 3. Dendrocopos minor; 4. Dendrocopos leucotos; 5. Dendrocopos syriacus; 6. Dryobates martius; 7. Picus canus; 8 . Picus viridis; 9. Picoides tridactylus; 10 . Jynx torquilla

B. Tibiotarsus, left side, cranial aspect: 1. Dendrocopos major; 2. Dendrocopos medius; 3. Dendrocopos minor; 4. Dendrocopos leucotos; 5. Dendrocopos syriacus; 6. Dryobates martius; 7. Picus canus; 8. Picus viridis; 9. Picoides tridactylus; 10. Jynx torquilla

Táblakép 7. A. Combcsont, baloldali, caudális nézet: 1. Dendrocopos major; 2. Dendrocopos medius; 3. Dendrocopos minor; 4. Dendrocopos leucotos; 5 . Dendrocopos syriacus; 6. Dryobates martius; 7. Picus canus; 8. Picus viridis; 9. Picoides tridactylus; 10. Jynx torquilla

B. Lábszárcsont, baloldali, craniális nézet: 1. Dendrocopos major; 2. Dendrocopos medius; 3. Dendrocopos minor; 4. Dendrocopos leucotos; 5. Dendrocopos syriacus; 6 . Dryobates martius; 7. Picus canus; 8. Picus viridis; 9. Picoides tridactylus; 10. Jynx torquilla 


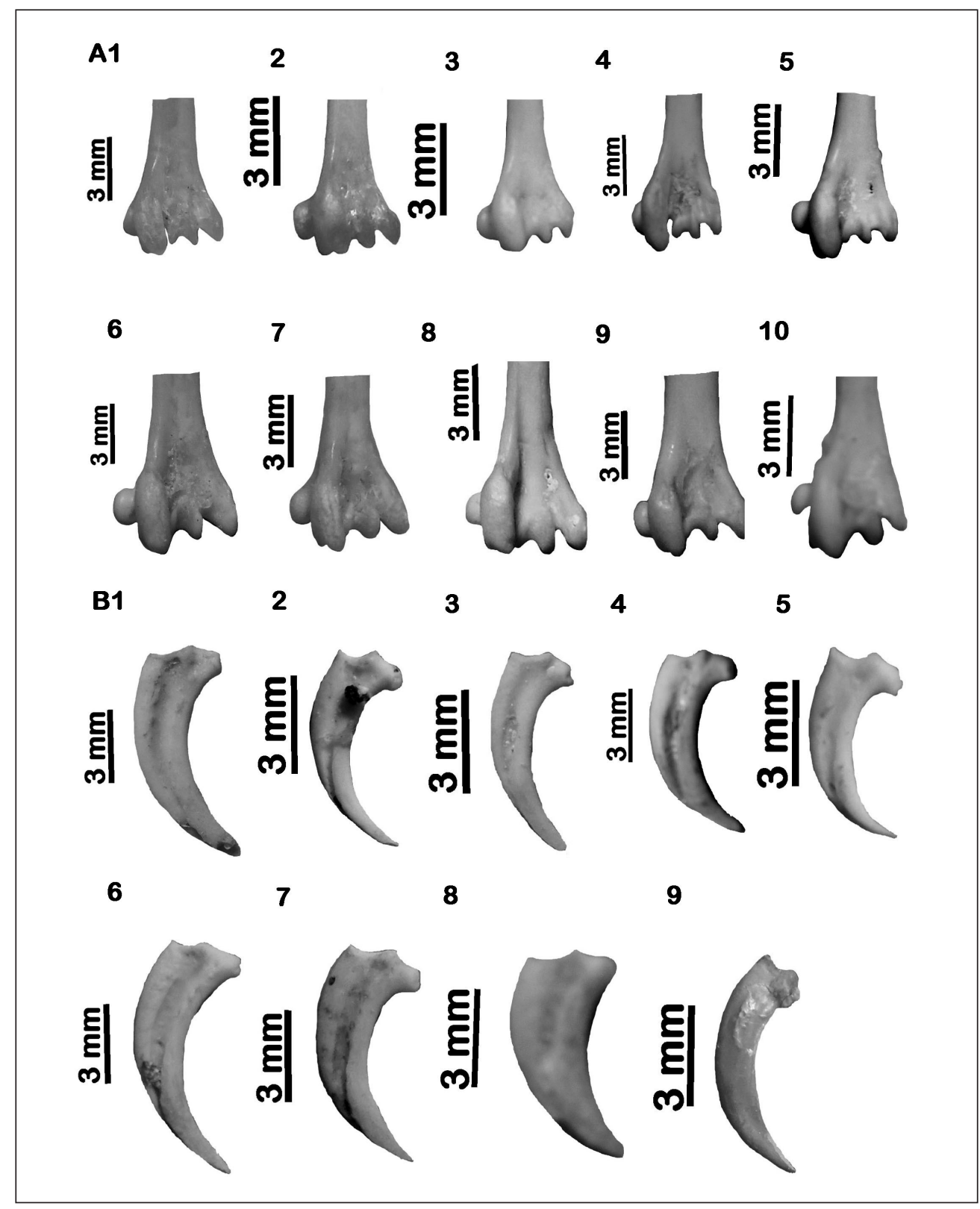

Plate 8. A. Tarsometatarsus, left side, dorsal aspect: 1. Dendrocopos major; 2. Dendrocopos medius; 3. Dendrocopos minor; 4. Dendrocopos leucotos; 5. Dendrocopos syriacus; 6. Dryobates martius; 7. Picus canus; 8. Picus viridis; 9. Picoides tridactylus; 10. Jynx torquilla

B. Claw, lateral aspect: 1. Dendrocopos major; 2. Dendrocopos medius; 3. Dendrocopos minor; 4. Dendrocopos leucotos; 5. Dendrocopos syriacus; 6. Picus canus; 7. Picus viridis; 8. Picoides tridactylus; 9 . Jynx torquilla

Táblakép 8. A. Csüd, baloldali, dorsális nézet: 1. Dendrocopos major; 2. Dendrocopos medius; 3. Dendrocopos minor; 4. Dendrocopos leucotos; 5. Dendrocopos syriacus; 6. Dryobates martius; 7. Picus canus; 8. Picus viridis; 9. Picoides tridactylus; 10. Jynx torquilla

B. Karomcsont, oldalsó nézet: 1. Dendrocopos major; 2. Dendrocopos medius; 3. Dendrocopos minor; 4. Dendrocopos leucotos; 5. Dendrocopos syriacus; 6. Picus canus; 7. Picus viridis; 8. Picoides tridactylus; 9. Jynx torquilla 
Respectively to skeletal parts, their characteristics are the following:

\section{Mandibula (Plate 2):}

- a. the tip of the beak is:

- very short: Jynx

- short: Picus

- long: Dendrocopos, Dryobates, Picoides

$-b$. the recess between the stems is:

- ovoid: Jynx, Picoides, Picus

- ovoid, with recess in the middle: Dendrocopos, Dryobates

- c. the stem is:

- very long: Jynx

- long: Picus

- short: Dendrocopos, Dryobates, Picoides

2. Coracoideum (Plate 3A):

$-\mathrm{a}$. the processus acrocoracoidalis is:

- straight, clublike: Picus

- medially protuberant: Dendrocopos, Dryobates

- medially pointening in a hook shape: Jynx, Picoides

$-b$. the medial part of the sternal end is:

- short and pointed: Dendrocopos major, D. minor, D. syriacus, Dryobates

- shortly protrusive: Picus

- protractedly protrusive: Dendrocopos leucotos, D. medius, Jynx, Picoides

- c. the lateral part of the sternal end:

- curves downward sharply: Picoides

- curves upward sharply: Picus

- curves downward bluntly: Dendrocopos leucotos, D. medius, Jynx

- straight: Dendrocopos major, D. minor, D. syriacus, Dryobates

3. Scapula (Plate 3B):

- a. the lateral projection is:

- cone-shaped: Dendrocopos

- curved, sharp: Dryobates

- thick, with a cut-off end: Picus

- narrow, long: Jynx, Picoides

$-b$. the dorsal projection is:

- cone-shaped: Dendrocopos, Dryobates, Jynx, Picus

- long, narrow: Picoides

\section{Humerus (Plate 4):}

- a. the crista biccipitalis is:

- rounded: Dendrocopos 
- cone-shaped: Dryobates, Jynx, Picus

- b. the processus supracondylaris dorsalis is:

- rounded: Jynx, Picus

- slightly protruding cone shape: Dendrocopos

- strongly protruding cone shape: Dryobates

5. Ulna (Plate 5):

- a. olecranon:

- pointed cone: Dendrocopos medius, D. syriacus, Jynx

- blunt cone: Dendrocopos minor, Dryobates, Picoides, Picus

- straight: Dendrocopos major, D. leucotos

- b. cotyla dorsalis:

- pointed cone: Dendrocopos, Dryobates, Picoides, Picus

- straight: Jynx

- c. the tuberculum carpale is:

- rounded: Dendrocopos minor, D. syriacus, Picus

- strongly protruding: Dendrocopos major, D. medius

- slightly protruding: Dendrocopos leucotos, Dryobates, Jynx, Picoides

6. Carpometacarpus (Plate 6A):

- a. the trochlea carpalis is:

- simple: Dendrocopos

- double: Dryobates, Jynx, Picoides, Picus

$-b$. the processus extensorius is:

- straight, with a rounded end: Dendrocopos leucotos

- straight blunt cone: Jynx

- oblique with a cut-off end: Picus

- oblique with a rounded end: Dendrocopos major, D. medius, D. minor, D. syriacus, Dryobates, Picoides

- c. the distal end of the metacarpus major is:

- straight, wavy: Dendrocopos leucotos, Jynx

- rounded: Dendrocopos major, D. medius, D. minor, D. syriacus

- oblique: Dryobates, Picoides, Picus

7. Phalanx proximalis digiti majoris (Plate 6B):

- a. the proximal end is:

- straight, wavy: Jynx

- oblique: Dendrocopos, Dryobates, Picoides, Picus

- b. the distal end is:

- straight: Picus canus

- protruding: Dendrocopos, Dryobates, Jynx, Picoides, Picus viridis

- c. the distal end of the dorsal side is:

- rounded: Jynx 
- cone-shaped: Picus viridis

- straight: Dendrocopos leucotor, D. syriacus, Dryobates, Picoides, Picus canus

- oblique: Dendrocopos major, D. medius, D. minor

\section{Femur (Plate 7A):}

$-\mathrm{a}$. the condylus lateralis is

- laterally rounded: Dendrocopos minor, D. syriacus, Jynx, Picoides

- laterally protruding: Dendrocopos leucotos, D. major, D. medius, Dryobates, Picus canus, $P$. viridis

The morphological homogeneity is significant in the case of this skeletal part. What differs is the relative length of the diaphysis: it is long and slim in the Jynx, medium length in the Picus, while shorter in other genera.

\section{Tibiotarsus (Plate 7B):}

- a. the tuberositas retinaculi is:

- well-developed: Dendrocopos leucotos, D. major, D. medius

- moderately developed: Dryobates, Jynx, Picoides, Picus

- undeveloped: Dendrocopos minor, D. syriacus

Homogeneity is significant in the case of this skeletal part. In case of Dendrocopos syriacus and the Dryobates, a protrusion can be located above the epicondylus medialis. The diaphysis of the Jynx is long and slim, that of the Dryobates, however, is relatively short and thickset, whereas in case of the other genera, it is medium-size.

\section{Tarsometatarsus (Plate 8A):}

- a. trochlea metatarsi II:

- pointed: Dendrocopos major, D. medius, D. minor, Dryobates, Picoides

- rounded: Dendrocopos leucotos, D. syriacus, Jynx, Picus

- b. trochlea metatarsi IV.:

- semicircular: Dendrocopos minor, D. leucotos, Picoides, Picus

- ovoidal: Dendrocopos major, D. medius, D. syriacus, Dryobates, Jynx

This bone is the most typical skeletal part of the Picidae, i.e. on the distal end of the caudal side of the tarsometatarsus and on the medial side of the trochlea, a well-developed, spur-like rowel can be found. This is none other than the trochlea metatarsi I. (c). In case of other bird species, the I. metatarsus holding the first finger is not grown to the tarsometatarsus, while for the Picidae, it is, and its trochea leans forward between trochlea metatarsi II. and III. This is also valid for the Picoides and the Jynx, even though the Picoides have three fingers.

\section{Distal phalanx (Plate 8B):}

- a. the tuberculum extensorium: 
- leans toward the apex: Dendrocopos major, D. minor, D. leucotos. Picoides

- leans forward: Dendrocopos medius, D. syriacus, Picus, Jynx

- b. the cotyla articularis is:

- symmetrically concave: Dendrocopos medius, D. minor, D. leucotos,

D. syriacus, Picus, Jynx

- asymmetrically concave: Dendrocopos major, Picoides

- c. the tuberculum flexorium is

- cone-shaped: Picoides

- protruding, rounded: Dendrocopos leucotos, D. medius

- protruding, prismatic: Dendrocopos major, D. minor, D. syriacus, Picus

- flattened: Jynx

The fact that the distal phalanges of the 4 toes can differ in size and somewhat in appearance has to be taken into account. Thus, the characteristics presented here are provided for information purposes only, as well as their lengths in the size chart. The Picoides only has 3 distal phalanges respectively to the three toes. We did not have the opportunity to examine the distal phalanges of the Dryobates, since they were not present on the single skeleton found in the collection.

\begin{tabular}{|c|c|c|c|c|c|c|c|c|c|c|c|}
\hline 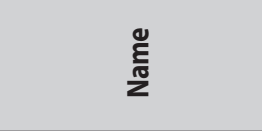 & 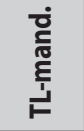 & 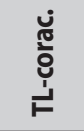 & 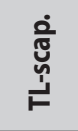 & 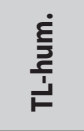 & 胥 & 它 & $\begin{array}{l}\frac{\dot{\varepsilon}}{0} \\
\frac{0}{0} \\
\stackrel{ }{ }\end{array}$ & 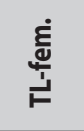 & 蒡 & 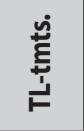 & 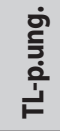 \\
\hline Dryobates martius & 71.12 & 40.41 & 32.41 & 53.81 & 62.51 & 31.41 & 18.52 & 42.51 & 51.31 & 35.31 & \\
\hline Dendrocopos major & 35.65 & 27.21 & 22.51 & 33.51 & 40.31 & 20.31 & 10.94 & 25.61 & 38.61 & 25.51 & 6.44 \\
\hline Dendrocopos medius & 34.11 & 21.01 & 19.41 & 28.81 & 34.21 & 18.31 & 10.56 & 20.21 & 32.31 & 21.06 & 6.61 \\
\hline Dendrocopos minor & 20.47 & 17.06 & 13.53 & 20.01 & 24.01 & 11.41 & 6.77 & 16.06 & 24.31 & 15.01 & 5.05 \\
\hline Dendrocopos syriacus & 35.88 & 27.24 & 22.48 & 32.57 & 40.69 & 18.51 & 9.94 & 23.59 & 35.84 & 24.01 & 5.23 \\
\hline Dendrocopos leucotos & 39.58 & 31.81 & 25.91 & 38.65 & 43.81 & 22.58 & 10.53 & 29.29 & 40.66 & 27.55 & 6.82 \\
\hline Picus viridis & 55.21 & 31.21 & 27.01 & 35.71 & 44.06 & 21.51 & 12.96 & 28.81 & 41.71 & 26.31 & 9.64 \\
\hline Picus canus & 51.03 & 30.21 & 27.02 & 36.21 & 42.41 & 20.42 & 11.06 & 28.51 & 41.21 & 26.51 & 9.31 \\
\hline Picoides tridactylus & 36.41 & 25.96 & 20.71 & 30.01 & 35.61 & 18.53 & 9.98 & 24.63 & 33.89 & 22.71 & 7.66 \\
\hline Jynx torquilla & 25.84 & 20.81 & 24.31 & 23.21 & 26.08 & 16.12 & 9.07 & 19.88 & 31.63 & 19.73 & 6.65 \\
\hline
\end{tabular}

Table 1. Size table of recent woodpeckers

Abbreviations: TL-mand. - total lenght of mandible in $\mathrm{mm}$; TL-corac. - total lenght of coracoid; TL-scap. - total lenght of scapula; TL-hum. - total lenght of humerus; TL-uln. - total lenght of ulna; TL-cmcp. - total lenght of carpometacarp; TL-ppdm. - total lenght of phalanx proximalis digiti majoris; TL-fem. - total lenght of femur; TL-tibts. - total lenght of tibiotars; TL-tmts. - total lenght of tarsometatars; TL-p.ung. - total lenght of phalanx ungularis

1. táblázat A recens harkályok mérettáblázata

Rövidítések: TL-mand. - állkapocs teljes hossza mm-ben; TL-corac. - hollócsőrcsont teljes hossza; TL-scap. - lapocka teljes hossza; TL-hum. - felkarcsont teljes hossza; TL-uln. - singcsont teljes hoszsza; TL-cmcp. - kézközépcsont teljes hossza;TL-ppdm. - II. kézujj, 1 ujjpercének teljes hossza; TL-fem. - combcsont teljes hossza; TL-tibts. - lábszárcsont teljes hossza; TL-tmts. - csüd teljes hossza; TL-p. ung. - karomcsont teljes hossza 


\section{Acknowledgements}

The author wishes to express his deep gratitude to Mihály Gasparik for access in recent bird bone collection in the Natural History Museum of Hungary, to Márton Venczel ("Tării Crișurilor" Museum from Oradea, Romania) for photos of the mandible of Dryobates martius, to referees for their help in the revision of the text and to József Vuts and Lóránd Abos for the language revision.

\section{References}

Ballmann, P. 1966. Die Vögel aus der altburdigalen Spaltenfüllung von Wintershof (West) bei Eichstätt in Bayern [The birds from the altburdigalen fissure filling of Wintershof (West) at Eichstatt in Bavaria]. See Ballmann 1969b for the published version of this thesis. - Unpub. Thesis, Universität München (in German)

Ballmann, P. 1969a Les oiseaux miocènes de La Grive-Saint-Alban (Isère) [Miocene birds Thrush-Saint-Alban (Isère)]. - Géobios 2: 157204. (in French)

Ballmann, P. 1969b Die Vögel aus der altburdigalen Spaltenfüllung von Wintershof (West) bei Eichstätt in Bayern [The birds from the altburdigalen fissure filling of Wintershof (West) at Eichstatt in Bavaria]. - Zitteliana 1: 5-61. (in German)

Čapek, V. 1917. A püspökfürdői preglaciális madárfauna [The Preglaciale bird fauna from Püspökfürdő]. - Barlangkutatás 5: 66-74. (in Hungarian)

Fischer, K. \& Stephan, B. 1977. Vogelknochenfunde aus Quartären Ablagerungen Südwestrumaniens [Bird bones from Quaternary deposits in Southwest Romania]. - Annalen für Ornithologie 1: 79-90. (in German)

Gál, E. 2002. Avifauna pleistocena a Romaniei [Pleistocene bird faunas of Romania]. - Unpublished C.Sc Thesis, Universitatea din Bucureşti, Facultatea de Geologie București (in Romanian)

Gál, E. 2007. Fowling in lowlands. Neolitic and Chalcholitic bird exploitation in South-East-Romania and the Great Hungarian Plain. - Archaeolinqua, Budapest

Jánossy, D. 1952. Az Istállóskői barlang aurignaci faunája [Aurignacian fauna from the Istállóskő Cave]. - Földtani Közlöny 82(4-6): 181-203. (in Hungarian)

Jánossy, D. 1954. Fossile Ornis aus der Höhle von Istállóskő [Fossile birds from the Istállóskő Cave]. - Aquila 55-58: 205-223. (in German)

Jánossy, D. 1955. Die Vogel-und Saugetierreste der Spätpleistozänen Schichten der Höhle von Istállóskő [The bird and mammalian remains of the Late Pleistocene Layers of the Istállóskő
Cave]. - Acta Archaeologica Academiae Sciencentiarum Hungaricae 5: 149-181. (in German)

Jánossy, D. 1965. Fossiler Vogelfauna aus Mousterien Schichten der Curata-Hohle (Rumanien) [Fossil bird fauna from Mousterian layers of Curata Cave (Romania)]. - Vertebrata Hungarica 7(1-2): 106116. (in German)

Jánossy, D. 1974. Die mittelpleistozäne Vogelfauna von Hundsheim (Niederösterreich) [The Middle Pleistocene avifauna of Hundsheim (Lower Austria)]. - Sitzungsberichte der Österreichischen Akademie der Wissenschaften, Mathematisch-Naturwissenschftliche Klasse, Abteilung I. 182: 211-257. (in German)

Jánossy, D. 1979. Plio-pleistocene bird remains from the Carpathian Basin. V. Podicipediformes, Ciconiiformes, Otidiformes, Columbiformes, Piciformes. - Aquila 86: 19-33.

Jánossy, D. 1981. Die altpleistozänen Vogelfaunen von Deutsch-Altenburg 2 und 4 (Niederösterreich) [The Early Pleistocene bird fauna of Deutsch-Altenburg 2 and 4 (Lower Austria)]. - Beiträge zur Palaontologie von Österreich 8: 375-391. (in German)

Jánossy, D. 1982. Új adatok az európai madárfauna kialakulásáról [New data on the evolution of European bird fauna]. - Földtani Közlemények 112: 449-453. (in Hungarian)

Jánossy, D. 1983. Lemming-remain from the older Pleistocene of southern Hungary (Villany, Somsich-hegy 2). - Fragmenta Mineralogica et Paleontologica 11: 55-60.

Jánossy, D. 1986. Pleistocene vertebrate faunas of Hungary. - Budapest, Akadémiai Kiadó \& Amsterdam, Elsevier

Jurcsák, T. \& Kessler, E. 1988. Evoluţia avifaunei pe teritoriul României (III.) [Evolution of the avifauna in the territory of Romania. Part III.]. - Crisia 18: 647-688. (in Romanian with English Summary)

Kessler, E. 1974. Avifauna postglaciară de la Cuina Turcului, Cazanele Mari, România [Postglacial avifauna from Cuina Turcului, Cazanele Mari, România]. - Tibiscus 11: 113-122. (in Romanian) 
Kessler, E. 1977. Avifauna zonei Crişurilor din perioada pliocenului până astăzi [Avifauna of Cris area from Pliocene to today]. - Unpublished C.Sc. Dissertation, Universitatea din Bucureşti, Facultatea de Biologie (in Romanian)

Kessler, E. 1982. Avifauna fosilă şi subfosilă a Munţilor Apuseni [Fossil and subfossil bird fauna from Apuseni Mountains]. - Nymphaea 10: 171181. (in Romanian)

Kessler, E. 1985a Material fosil şi subfosil de păsări din Defileul Dunării de la Porţile de Fier [Fossil and subfossil bird remains of Iron Gates from Danube Gorge]. - Drobeta, pp. 337-339. (in Romanian)

Kessler, E. 1985b Contribuţii noi la studiul avifaunelor cuaternare din România [New contributions to the study of Quaternary bird faunas in Romania]. - Crişia 15: 485-491. (in Romanian)

Kessler, J. 2009. Új eredmények a Kárpát-medence neogén és negyedidőszaki madárvilágához. II. rész [New results with regard to the Neogene and Quaternary avifauna of the Carpathian Basin. Part II.]. - Földtani Közlöny 139(3): 251-271. (in Hungarian with English Summary)

Kessler, J. 2013. A Kárpát-medence madárvilágának öslénytani kézikönyve [Paleontological handbook of birdlife in the Carpathian Basin]. Könyvmühely, Miskolc, Hungary (in Hungarian)

Kessler, J. (E). 2014. Fossil and subfossil bird remains and faunas from the Carpathian Basin. Ornis Hungarica 22(2): 65-125. DOI: 10.2478/ orhu-2014-0019

Kormos, T. 1913. Kleinere Mitteilungen aus dem ungarischen Pleistozän [Small releases from the Hungarian Pleistocene]. - Centralblatt für Mineralogie, Geologie und Palaontologie 1913: 1317. (in German)

Lambrecht, K. 1912a A borsodi Bükk fossilis madarai. - Fossile Vögel des Borsoder Bükkgebirges [Fossil birds of the Bükk Mountains from Borsod]. - Aquila 19: 270-287. (in Hungarian and German)

Lambrecht, K. 1912b Magyarország fossilis madarai. - Die fossilen Vögel Ungarns [The fossil birds of Hungary]. - Aquila 19: 288-320. (in Hungarian and German)

Lambrecht, K. 1915. Fossilis nagy fülesbagoly (Bubo maximus Flemm.) és egyéb madár maradványok a magyarországi pleistocenből [Fossil's Big Eared Owl (Bubo maximus Flemm.) and other bird remains in Hungarian Pleistocene]. - Aquila 22: 177-187. (in Hungarian)

Lambrecht, K. 1916. Az első magyar preglaciális madárfauna - Die erste ungarische praglaziale Vogelfauna [The first Hungarian Preglaciale bird fauna]. - Aquila 22: 165-172. (in Hungarian and German)

Lambrecht, K. 1933. Handbuch der Palaeornithologie [Handbook of Palaeornithology]. - Gebrüder Borntraeger, Berlin (in German)

Malez, M. 1961. Pecinska hijena iz indije kod Voce [The Cave Hyaenas come from Vindija Cave]. Geologiceskij Vjesnik 14: 221-244. (in Croatian)

Malez, V. 1973. Fosilne ptice Jugoslavije [Fossil birds from Yugoslavia]. - Unpublished Dissertation, Zagreb University (in Croatian)

Malez, V. 1984. Paleornitološki ostaci iz kvartarnih naslaga nekih spilja Hrvatske i Slovenije [Pale ornithological remains from the Quaternary Sediments of some Croatian and Slovenian caves]. - In: Deveti jugoslavenski speleoloski kongres, Zbornik predavanja (in Croatian)

Malez, V. 1986. Paleoornitološka istrazivanja u našim krajevima [Paleornithological research in our region]. - In: Mestrov, M. \& Sušić, G. (eds.) Ornitologija u Hrvatskoj, JAZU, Zagreb (in Croatian)

Malez, V. 1988. Pleistocenska ornitofauna iz spilje Vindije u sjevernozapadnoj Hrvatskoj [Pleistocene bird fauna from Vindija Cave in Northwestern Croatia]. - Rad Jugoslavenske Akademije Znanosti i Umjetnosti, Varazdin 2: 31-203. (in Croatian)

Malez-Bačić, V. 1979. Pleistocenska ornitofauna iz Šandalje u Istri te njezino stratigrafsko i paleoekološko značenje [Pleistocene bird fauna from Šandalja in Istria and its stratigraphic and paleoecological significance]. - Palaeontologia Jugoslavica 21: 1-46. (in Croatian)

Mayr, G. 2005a A tiny barbet-like bird from the Lower Oligocene of Germany: the smallest species and earliest substantial fossil record of the Pici (woodpeckers and allies). - The Auk 122(4): 1055-1063. DOI: 10.1642/0004-8038(2005)122[1055:ATBBFT]2.0.CO;2

Mayr, G. 2005b Phylogenetic affinities and composition of the early Eocene Gracilitarsidae (Aves, ?Piciformes). - Neues Jahrbuch für Geologie und Paläontologie, Monatshefte, 2005(1): 1-16.

Mayr, G. 2005c Phylogenetic affinities of the enigmatic avian taxon Zygodactylus based on new material from the early Oligocene of France. - Journal of Systematic Palaeontology 6(3): 333-344. DOI: 10.1007/s12542-012-0133-5

Mayr, G. 2006. First fossil skull of a Paleogene representative of the Pici (woodpeckers and allies) and its evolutionary implications. - Ibis 148: 824-827. DOI: 10.1111/j.1474-919X.2006.00584.x

Mayr, G. \& Gregorova, R. 2012. A tiny stem group representative of Pici (Aves, Piciformes) from the early Oligocene of the Czech Republic. 
- Paläontologische Zeitschrift 86: 333-343. DOI: 10.1007/s12542-012-0133-5

Mayr, G. \& Zelenkov, N. 2009. New specimens of zygodactylid birds from the middle Eocene of Messel, with description of a new species of Primozygodactylus. - Acta Palaeontologica Polonica 54(1): 15-20. DOI: 10.4202/app.2009.B103

Mlikovskỳ, J. 2002. Cenozoic Birds of the World, Part 1. Europe. - Ninox Press, Praha

Nehring, A. 1880. Uebersicht über vierundzwanzig mitteleuropäische Quartär-Faunen [Survey of twenty-four Central European Quaternary fauna]. - Zeitschrift der Deutschen Geologischen Gesellschaft 32: 468-509. (in German)

Nehring, A. 1881. Dr. Roth's Ausgrabungen in Oberungarischen Höhlen [Dr. Roth's excavations in North Hungarian caves]. - Zeitschrift für Ethnologie 13: 96-109. (in German)

Pike-Tay, A., Bartosiewicz, L., Gál, E. \& Whitle, A. 2004. Body part representation and seasonility: sheep/goat, bird and fish remains from Early Neolitic Ecsegfalva 23 SE Hungary. - Journal of Taphonomy 2(4): 221-246.

Róth, S. 1881. Szepesmegye néhány barlangjának leírása [Description of some caves in Szepes
County]. - Mathematikai és Természettudományi Közlemények 16: 613-648. (in Hungarian)

Soergel, E. 1966. Die Vogelreste [The Bird Remains]. In: Ehrenberg, K. (ed.) Die Teufels-oder Fuck-senlucke bei Eggenburg (NÖ) [The Devil or Fuck senlucke at Eggenburg (NA)]. - Denkschriften der Mathematisch-Naturwissenschftliche Klasse der Österreichischen Akademie der Wissenschaften (in German)

Tyrberg, T. 1998. Pleistocene birds of the Palearctic: a catalogue. - Nuttall Ornithological Club, no. 27., Cambridge, Massachusetts

Wettstein, O. V. \& Mühlhofer, F. 1938. Die Fauna der Höhle von Merkenstein in N-Ö [The fauna of the Merkenstein Cave in North Austria]. - Archiv Naturgeschichte, new series 7(4): 514-558. (in German)

Winkler, H. 2015. Phylogeny, biogeography and systematics. - Denisia 36, zugleich Kataloge des oberösterreichischen Landesmuseums Neue Serie 164: 7-35.

Umans'ka, A. S. 1981. Miocenovye pticy Zapadnogo Pričernomor'ja USSR. Soobščenie II. [Miocene birds of western Pričernomor'e. Communication II.]. - Vestnik Zoologii 17(3): 17-21. (in Russian)

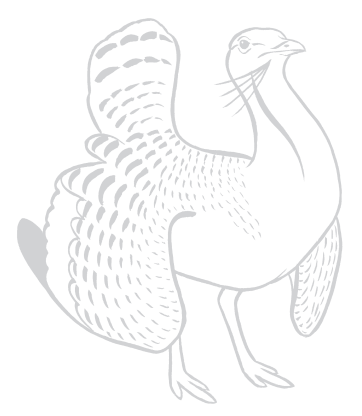

